\title{
Development Framework of Emergency Call Application in Pregnant Women
}

\author{
Antono Suryoputro*, Rani Tiyas Budiyanti** \\ ** M Author Correspondence: ranitiyasbudiyanti@gmail.com \\ *Public Health Faculty, Diponegoro University, Indonesia \\ ** Public Health Faculty, Diponegoro University, Indonesia
}

\begin{tabular}{l}
\hline I N D E X I N G \\
\hline Keywords: \\
Framework \\
Emergency call \\
Pregnant women
\end{tabular}
\begin{abstract}
A B S T R AC T
Referral problem in high risk pregnancy can increase the pregnant woman mortality. Beside of refferal's delay in emergency case, delay in knowing the danger sign also be the problem. In development of technology, much information system can be applied to recognize the danger signs of pregnancy and request immediate help in emergency case. One of them is using application in smartphone. This study aims to develop framework of emergency call application in pregnant woman. This study was literature review research from journal year 2009-2019, book, preceding that related with danger signs of pregnancy and emergency call apss in pregnant woman. Time research was done in July until Agustus 2019. The development framework of emergency call application in pregnant woman consists of personal information, danger sign information, and calculator prediction of risk pregnancy, emergency button, chat feature, and examination history. It needs to identify health professional, health care, and family that can be contacted immediately. The Conclusion is implementing an emergency system application for pregnant women, good technology literacy and joint commitments are needed.
\end{abstract}

Kata kunci:

Kerangka konsep

Panggilan darurat

Ibu hamil
Permasalahan rujukan di kehamilan dengan resiko tinggi dapat meningkatkan kematian ibu hamil. Selain karena disebabkan keterlambatkan rujukan, keterlambatan dalam mengenali tanda kegawat daruratan juga menjadi permasalahan. Dalam perkembangan teknologi, berbagai sistem informasi dapat digunakan untuk membantu mengenali tanda kegawatdaruratan pada kehamilan dan meminta pertolongan segera dalam kasus emergensi. Salah satunya dengan pemanfaatan aplikasi pada smartphone. Penelitian ini bertujuan untuk mengembangkan kerangka konsep pengembangan aplikasi kegawatdaruratan pada ibu hamil. Penelitian ini menggunakan metode literature review dengan sumber berasal dari jurnal, buku, dan proseding dari tahun 2009 hingga tahun 2019 yang berkaitan dengan tanda bahaya dan aplikasi kegawatdaruratan pada ibu hamil. Penelitian dilakukan pada bulan Juli hingga Agustus 2019. Hasil penelitian ini adalah pengembangan kerangka kerja aplikasi kegawatdaruratan pada ibu hamil terdiri dari informasi individu, informasi mengenai tanda bahaya, kalkulator prediksi resiko kehamilan, tombol darurat, fitur chat, dan riwayat pemeriksaan. Selain itu diperlukan data mengenai nomor tenaga kesehatan, fasilitas kesehatan, dan keluarga terdekat yang dapat dihubungi ketika terjadi kegawatdaruratan. Untuk dapat mengimplementasikan aplikasi kegawatdaruratan untuk ibu hamil, diperlukan dukungan dan komitmen dari pihak terkait serta diperlukan literasi digital yang baik.

(C) 2019 JMMR. All rights reserved

Article History: Received 2019-Oct-01; Revised 2019-Dec-20; Accepted 2019-Dec-25

\section{INTRODUCTION}

Maternal mortality still is the problem in many countries especially in developing countries. Even though maternal mortality ratio represent risk associated with obstetric risk and also a Sustainable Development Goals indicator. ${ }^{[1]}$ Complication during pregnancy can lead death and disability among pregnant women. According to World Health Organization (WHO), maternal death is the death of woman while pregnant or within 42 days of termination pregnancy, from any causes related to pregnancy or its management, but not from accidental causes. ${ }^{[2]}$ There are roughly 303.000 maternal deaths are caused as a result of pregnancy and childbirth related complications. ${ }^{[2]}$

Referrals delay is the problem that often occurs in many developing countries, such as Indonesia. In Semarang City, Indonesia, the maternal mortality rate can be occurred by various types of referral delay, 
delay in decision-making, delay in accessing health services, and delay in acquiring health services. ${ }^{[3]}$

There are many problem in referral case that can cause mortality in pregnant women. First, lack of information in pregnant woman especially in first pregnancy, and unwanted pregnancy. Based on Handriani (2015), the poor referral in pregnant woman in Sidoarjo City, Indonesia was caused by low education of pregnant woman in danger sign of pregnancy, and also the high risk pregnant woman not in good monitoring. ${ }^{[4]}$ Previous experience by women of early pregnancy complication also important to reduce maternal mortality in Nigeria. ${ }^{[5]}$ It related with ignorance, traditional myths, family restriction on seeking better care, and dependency of traditional birth. ${ }^{[6]}$ Many women don't give attention with her pregnancy in some cases. In unwanted pregnancy, the mother often feel shy to get antenatal care in health care. She usually look for the information herself, from internet and social media that unvalid information and can mislead the information. ${ }^{[7]}$ They also lack of awareness with their pregnant especially about danger sign. If there are some danger sign that happen, they also confused to say it to another person.

In the first pregnancy, the mother has lack of experience about it. They don't have experience about the risk of pregnancy and the danger sign about it. ${ }^{[8]}$ They look for the information for many source. The information must be valid so it doesn't make danger to the pregnant women. Second, the delay of referral can happen if the pregnant women doesn't know the family and health professional that closed with them. It is important to call the people soround them to ask help immediately. ${ }^{[9]}$ Third, knowledge and estimation about of risk in pregnancy. If the pregnant women know their condition or pregnancy risk, they will be aware and ready for asking help if there are any emergency case happen. ${ }^{[10]}$ They prepare for the nearest health care or health professional, money, person in charge, and also prevent the activity that can make worse condition.

Fourth, lack of interaction between the pregnant woman and her midwife or medical doctor. Most of mother just have interaction in offline condition trough antenatal care. They limited to ask some information that related with pregnancy. ${ }^{[1]}$

In this technology era, it should be unhappen. The pregnant mother can consult the pregnancy condition also in online consultation through telemedicine or instant messaging. And also referral delay should be can reduced. The expansion of mobile phones or smartphone usage presents potential opportunity to improve maternal service delivery. ${ }^{[12]}$

\section{RESEARCH METHOD}

This study was literature review research from journal year 2009-2019, book, proceeding that related with the research such as 'danger signs of pregnancy', 'high risk pregnancy', 'pregnant women', and 'application'. Time research was done in July-Agustus 2019.

\section{RESULT AND DISCUSSION}

\section{Definition's Agreement}

Before develops the framework of emergency calls application, definition's agreement about many terms related with emergency situation in pregnant women must be done clearly such as definition of pregnant women, danger sign of pregnancy, risk pregnancy, emergency case in pregnancy, and application.

\section{Pregnant Women}

Pregnant women means someone who has pregnancy. Since 1960s, the begin of pregnancy still debatable. Many legal countries states that the began of pregnancy from fertilization and conception, but other countries states that the began from implantation. ${ }^{[13]}$ In Indonesia, based on Minisitry of Health Regulation in Indonesia, pregnancy starts from conception until fetus delivery. Normal pregnancy time approximately 280 days (40 weeks or 9 months). ${ }^{[14]}$ On the other hand, based on American College of Obstetricians and Gynecologitsts (ACOG), a pregnancy is considered to be established only when the process of implantation is complete until delivery. ${ }^{[15]}$ So that, the pregnancy can began from conception or implantation until delivery.

\section{Risk of Pregnancy}

Risk of pregnancy is the risk status of pregnancy based on pregnancy risk factors in the form of low riskpregnancies, high risk- pregnancies, and very high riskpregnancies. Risk factor of high risk- pregnancy involve :

- $\quad$ Existing health condition such as diabetes, high blood pressure, and being HIV positive. ${ }^{[16]}$

- Overweight and obesity. Obesity can increase risk of high blood pressure, preeclampsia, gestational diabetes, still birth, neural tubes defect and raise of infant's risk heart problems. ${ }^{[17]}$ 
- Multiple births. Risk of complication in women with multiple fetuses (twins and more) is higher. The complication can include preeclampsia, premature labor, and preterm birth. ${ }^{[18]}$

- $\quad$ Young and old maternal age. Pregnancy in young women and old women more than 25 years increase the risk of preeclampsia and gestational high blood pressure. ${ }^{[17]}$

There many calculation or scoring system regarding the risk factor. In Indonesia, there are prediction score to know the risk of pregnancy that was called " Poedji Rochjati Score". ${ }^{[19]}$ That's score based on many risk factor such as age, pregnancy distance, children number, delivery history, section casearia history, disease such as anemia, tuberculosis, diabetic, malaria, heart failure, and sextual transmitted disease. Oedem, gemelli, intra uterine fetal death (IUFD), bleeding, blood pressure, and breach positon also the risk factor prediction. The number of the score can divides the risk of pregnancy to 3 types low risk pregnancy, high risk pregnancy, and very high risk pregnancy ${ }^{[19]}$ Risk of pregnancy also affect or consider the labor's places. In low risk pregnancy, the pregnant mother can consider labor in private midwives practice or healthcare. In high pregnancy, pregnant mother should labor in healthcare with medical doctor. Pregnant mother that has high risk pregnancy should labor in obstetrician and gynecology specialist. $^{[20]}$

\section{Danger Sign in Pregnancy}

Pregnant women should know the danger sign in pregnancy. It should differ with uncomfortable symptoms but no serious problems. Normal discomforts of pregnancy can include nausea (especially in the first 3 months), heartburn, a need to urinate often, backache, breast tenderness and swelling, and also tiredness. ${ }^{[21]}$

Being aware with danger sign is important to help the pregnant women to know when they need special care from healthcare provider. There are many danger sign of pregnancy:

\section{Miscarriage}

Bleeding, contraction, and cramping during first 20 weeks pregnancy can be sign of miscarriage. ${ }^{[22]}$ Other signs include gush or bleeding from vagina. In early pregnancy there are sometimes happen physiological bleeding, but it must be differ with pathological bleeding. Miscarriage can happen both complete and incomplete that can lose the baby.

\section{Tubal Pregnancy}

Pain and pressure in lower belly in first 3 months of pregnancy can be sign of fertilizied egg is outside uterus that called tubal or ectopic pregnancy. Pain may be worse and sometimes spread in the shoulder. The pregnant women also feel dizzy, nausea, and vomiting. ${ }^{[23]}$

Severe Morning Sickness

Nausea and vomiting is normal sign in the first 3 months of pregnancy, but severe nausea and vomiting can be danger sign that could lose weight and make dehydration so that the baby not get enough nutrients and need to be treated in healthcare. Morning sickness usually be better after first 3 month pregnancy. ${ }^{[2]}$

\section{Pretem Labor}

Normal labor occurs between weeks 37-40 of pregnancy. Labor that happens between 20 weeks until 37 weeks was called pretem labor. The signs of pretem labor can be cramps, pelvic pressure, backache, and bleeding or vaginal discharge. ${ }^{[25]}$

\section{Infection}

Infection or illness of infection can appear if temperature over $100^{\circ} \mathrm{F}$ or $37.8{ }^{\circ} \mathrm{C}$. Fever or infection can lead pretem labor. So that it must be treated with antibiotics or other medicines. ${ }^{[26]}$

\section{Less Baby Movements}

In 20 weeks, pregnant women should feel the baby movements. Each baby has own pattern and movement. If there is less or different pattern of baby movements pregnant women should be aware and should go to healthcare. $^{[27]}$

\section{Preeclampsia and High Blood Pressure}

High blood pressure can be danger symptoms in pregnancy such as gestasional hypertensi, preeclampsia, and soon. Symptoms of preeclampsia can include headache, swelling of your feet, ankle, face, and hands, proteinuria, and blured vision. ${ }^{[28]}$ Danger sign of preeclampsia can in form of blurred vision, seizure, and unconsciousness that can cause brain, liver, kidney, heart, or eye damage. ${ }^{[29]}$

\section{Problems with the Placenta}

Vaginal bleeding in second or third semester of pregnancy can indicate placenta problem such as solution placenta, vasa previa, and placenta previa. ${ }^{[30]}$ Bleeding in first trimester pregnancy can be sign of abortus. In second trimester, bleeding can be sign of solutio plasenta or 
plasenta previa. Bleeding in solutio plasenta more dark than plasenta previa. It also tenderness sign in mother'stomach. Bleeding in plasenta previa more bright and much volume. It depends on the location of plasenta, marginal or total plasenta previa. In third semester, bleeding can happen in plasenta previa, abruption plasenta, and vasa pervia. In the last time of pregnancy, blood mixed with mucus can be delivery sign. So it must differ with the bloody sign. ${ }^{[30]}$

\section{Development Framework of Emergency Calls Application in Pregnant Woman}

Based on the literature review, the development framework of emergency call application in pregnant women consists of personal information, danger signs of pregnancy information, calculator prediction of risk pregnancy, emergency button, chat feature, examination history.

\section{Personal Information}

Personal information is important to show the information of the mother. It contains of name, age, address, the pregnancy, abortus history, delivery history, estimated born date, first date in the last menstruation schedule, family, and the midwife that closed with the mother. ${ }^{[31]}$ This information can shows obstetric status and can give information about the closed family and health professional. It's very important to call them accidentally, if any danger sign happen

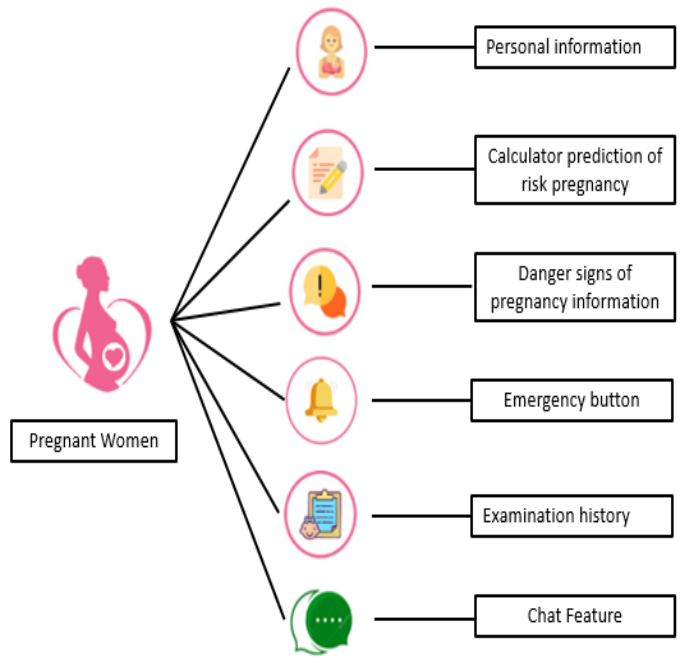

Figure 1. Design framework of Emergency Calls Application in Pregnant Women

\section{Danger sign of pregnancy information}

It's important to know the danger sign of pregnancy for example the bleeding and unconscious, fever, and severe nausea. It can be the sign of preterm labor, miscarriage, preeclampsia, infection, and hyperemesis gravidarum. ${ }^{[32]}$ So, if the pregnant mother have sign of danger sign in pregnancy, they must asking for help immediately.

\section{Calculator prediction of risk pregnancy}

If the pregnant women know her risk of pregnancy earlier they can be aware with their condition. ${ }^{[33]}$ The pregnant women in high risk pregnancy should have antenatal care and monitored by health professional such as midwive or doctor. ${ }^{[19]}$ Very high risk pregnant women should be monitor by obstretic and gyneacology specialist. ${ }^{[19]}$ They must be have intense and closed monitoring.

\section{Emergency button}

In emergency situation, someone often be panic and don't know what should they do. Who will be called in this situation and where they can asking for help? Emergency button was needed in this situation that can connect them with closed health professional or health care. Of course, they must save the number of emergency call in their application. It also better if the emergency button can send the pregnant location with GPS location. ${ }^{[34]}$ So that, the rescue can arrive in location by GPS. It will be more accurate and reduce the respon time.

\section{Chat feature}

In this era, online medical consultation can be the choice of the millennial pregnant women because it more flexible and cheaper. ${ }^{[35]}$ They can ask for many health informantion whenever and wherever. But, it more likely that the health professional know the pregnant women condition in previous offline antenatal care. So that, it doesn't happen the misdiagnosis and make harm to the pregnant women.

\section{Examination History}

Examinantion history feature is important in emergency application of pregnant women. It because the history can be personal health record that more efficient and can bring in everywhere and everytime. ${ }^{[36]}$ If they go to another midwife or medical doctor, they can show the examination history, so the new midwife can know the previous condition of the pregnant women. The 
examination history can monitor the condition of the pregnant women especially in very high risk condition.

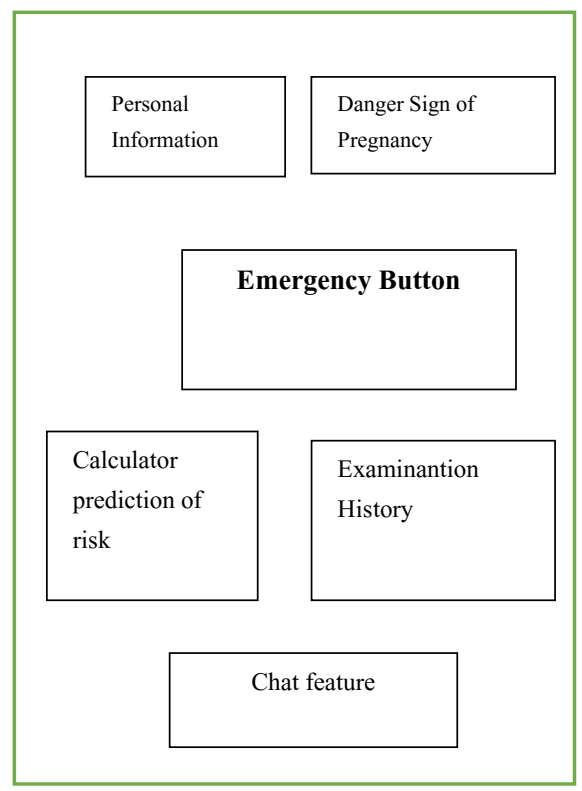

Figure 2. Design feature of emergency calls application in pregnant women

Altough, the using of emergency calls application can reduce the reffereal problem of pregnant women. There's also the challenge for using it such as the mother's literacy. The should get used to the smartphone, so if there were some emergency case they can push the emergency button. It also need of commitment between healths professional to give the best care to patient. They should come to the location or give the respon when the patient gives the emergency sign. The procedure and regulation about it should be developed so that the application can used wisely and not disturb the other person.

\section{CONCLUSION}

Emergency calls application has potency to reduce referral problem of pregnant women through the feature such as personal information, danger sign of pregnancy information, calculator predicition in risk pregnancy, emergency button, chat feature, and examination history. It needs to identify health professional, health care, and family that can be contacted immediately. To implement an emergency system application for pregnant women, good technology literacy and joint commitments are needed.

\section{ACKNOWLEDGMENT}

Thank you for Public Health Faculty, Diponegoro University, and Semarang, Indonesia who have funded this research

\section{REFERENCE}

1. World Health Organization (WHO): True magnitude of stillbirths and maternal and neonatal deaths underreported.Media Centre,2016. Available from: https://www.who.int/news-room/detail/16-08-2016-truemagnitude-of-stillbirths-and-maternal-and-neonatal-deathsunderreported

2. World Health Organization (WHO): Maternal Mortality Ratio (Per $100 \quad 000$ live births). Available from: https://www.who.int/healthinfo/statistics/indmaternalmorta lity/en/

3. Dewi Sari Rohmayani. Actors Affecting the Decrease of Maternal Mortality Rates and Problems Related to Birth Services. Jurnal Kesehatan Masyarakat (Kemas); Volume (13): 3. 2018. Available from : https://journal.unnes.ac.id/nju/index.php/kemas/article/vie w/11312

4. Indah Handriani and Soenarnatalina Melanjani. The Effect of Referral Process and Complications to Maternal Mortality. Jurnal Berkala Epidemiologi: Volume (3) : 3 . 2015. Available from : https://ejournal.unair.ac.id/index.php/JBE/article/view/1700

5. Ntoimo, LF;Okonoufua FE, Ogu RN, Galadanci HS, Gana M, Okike ON, Agholor KN, Abdus-Salam RA, Durodola A, Abe E, Randawa AJ. Prevalence and risk factor for maternal mortality in Reffereal Hospital in Nigeria : A Multicenter Study. International Journal of Women Health Volume 10. Pp : 69-76. 2018.

6. Iswas A, Dalal $\mathrm{K}$, Abdullah AS, et al. : Maternal complications in a geographically challenging and hard to reach district of Bangladesh: a qualitative study. F1000Res. September. 2016.

7. Rebecca L Dekker, Sarah King, Kara Lester. Social Media and Evidence-Based Maternity Care : A Cross-Sectional Survey Styudy. The Journal of Perinatal Education;25 (2):105-115. 2016

8. Carin Modh, Ingela Lundgren, Ingegerd Bergborn. First time pregnant women's experience in early pregnancy.Int $\mathrm{J}$ Qual Stud Health Well-Being: 6 (2). 2011.

9. Andrea B, Pembe Columba, K. Mbekenga, Pia Olsson, and Elisabeth Dari. Why do Women Not Adhere to Advice on Maternal Refferal in Rural Tanzania? Narratives of Women and Their Family Members. Glob Health Action: 10 (1). 2017.

10. Giuseppe Esposito, Rosella Ambrosio, Fransesco Napolitano, and Gabriella Di Giuseppe, Stephen D Ginsberg (Editor). Women's Knowledge, Attitudes and 
Behaviour about Maternal Risk Factor in Pregnancy. PLoS One; 10(12).2015.

11. Maureen I Heaman, Wendy Sword, Lawrence Elliott, Michael Moffatt, Michael E Helewa, Heather Morris Patricia Gregory, Lynda Tiaden, and Catherenie Cook. Barriers and Facilitators related to use of Prenatal Care by Inner-City Women : Perceptions of Health Care Providers. BMC Pregnancy Childbirth. 15: 2. 2015.

12. Ally S. Nyamawe and Hassan Seif. The Role of ICT in Reducing Maternal and Neonatal Mortality Rate in Tanzania. International Journal of Computer Applications. Volume 95(13). 2014.

13. Christoper M. Gacek. Conceiving "Pregnancy" US. Medical Dictionaries and Their Definitions of Conception and Pregnancy. Family Research Council. 2009. Available from: https://downloads.frc.org/EF/EF09D12.pdf

14. Ministry of Health Regulation Number 97 year 2014 on Health Services Befor Pregnancy, Pregnancy, and After Pregnancy, Contarception Services and Heath Reproduction Healthcare.

15. Rachel Benson Gold. The Implication of Defining When a Woman Is Pregnant. Available from: https://www.guttmacher.org/sites/default/files/article_files/ gr080207.pdf

16. American College of Obstetricians and Gynecologists. 2012. HIV and Pregnancy. Available from: http://www.acog.org/ /media/For\%20Patients/faq113.pdf? $\mathrm{dmc}=1 \& \mathrm{ts}=20120730 \mathrm{~T} 1640322605$

17. American College of Obstetricians and Gynecologists. ACOG Practice Bulletin No.156: Obesity in Pregnancy. Obstetrics and Gynecologi; 126(6). 2015

18. Hamilton, BE, Martin JA, Osterman MJ, Curtin, S,C and Mathews TJ. Births : Final Data for 2014. National Vital Statistics Reports : 64 (12). 2015

19. Widarta, Gede Danu; Laksana, Muhammad Ardian Cahya;Purnomo, Windu. Deteksi Dini Risiko Ibu Hamil dengan Kartu "Skor Poedji Rochjati" dan Pencegahan Faktor Empat Terlambat. Majalah Obstetri dan Ginekologi Vol.23. No.1. 2015. Available from: https://ejournal.unair.ac.id/MOG/article/view/2100

20. Lianne Holten, Martine Hollander, Esteriek de Miranda. When the Hospital Is No Longer an Option: A Multiple Case Study of Defining Moments for Women Choosing Home Birth in High-Risk Pregnancies in The Netherlands. Qual Health Res. 2018 Oct; 28(12): 1883-1896

21. K.J. Sapra, G.M. Buck Louis, R. Sundaram, K.S. Joseph, L.M. Bates, S. Galea, C.V. Ananth. Signs and symptoms associated with early pregnancy loss: findings from a population-based preconception cohort. Hum Reprod. 2016 Apr; 31(4): 887-896.

22. Stina Lou, Michal Frumer, Mette M. Schlütter, Olav B. Petersen, Ida Vogel, Camilla P. Nielsen. Experiences and expectations in the first trimester of pregnancy: a qualitative study. Health Expect. 2017 Dec; 20(6): 1320 1329

23. Florin-Andrei Taran, Karl-Oliver Kagan, Markus Hübner, Markus Hoopmann, Diethelm Wallwiener, Sara Brucker. The Diagnosis and Treatment of Ectopic Pregnancy. Dtsch Arztebl Int. 2015 Oct; 112(41): 693-704

24. Noel M. Lee, Sumona Saha. Nausea and Vomiting of Pregnancy. Gastroenterol Clin North Am. 2011 Jun; 40(2): 309-vii

25. Ali asghar Halimi asl, Saeed Safari, Mohsen Parvareshi Hamrah. Epidemiology and Related Risk Factors of Preterm Labor as an obstetrics emergency. Emerg (Tehran) 2017; 5(1): e3

26. Athena P. Kourtis, Jennifer S. Read, Denise J. Jamieson. Pregnancy and Infection. N Engl J Med. 2014 Jun 5; 370(23): 2211-2218

27. Delaram M, Jafarzadeh L. The Effects of Fetal Movement Counting on Pregnancy Outcomes. $J$ Clin Diagn Res. 2016;10(2):SC22-SC24. doi:10.7860/JCDR/2016/16808.7296

28. Maria Portelli and Byron Baron. Clinical Presentation of Preeclampsia and the Diagnostic Value of Proteins and Their Methylation Products as Biomarkers in Pregnant Women with Preeclampsia and Their Newborns. Journal of Pregnancy. Volume 2018.

29. Sarosh Rana, Elizabeth Lemoine, Joey Granger, S. Ananth Karumanchi. Preeclampsia: Pathophysiology, Challenges, and Perspectives. Circulation Research. 2019;124:10941112

30. Silver RM. Abnormal Placentation: Placenta Previa, Vasa Previa, and Placenta Accreta. Obstet Gynecol. 2015 Sep;126(3):654-68

31. Liu J, Tuvblad C, Li L, Raine A, Baker LA. Medical record validation of maternal recall of pregnancy and birth events from a twin cohort. Twin Res Hum Genet. 2013;16(4):845-860. doi:10.1017/thg.2013.31

32. Mwilike B, Nalwadda G, Kagawa M, Malima K, Mselle L, Horiuchi S. Knowledge of danger signs during pregnancy and subsequent healthcare seeking actions among women in Urban Tanzania: a cross-sectional study. BMC Pregnancy Childbirth. 2018;18(1):4. Published 2018 Jan 3. doi:10.1186/s12884-017-1628-6

33. Goyal NK, Hall ES, Greenberg JM, Kelly EA. Risk Prediction for Adverse Pregnancy Outcomes in a Medicaid Population. J Womens Health (Larchmt). 2015;24(8):681688. doi:10.1089/jwh.2014.5069

34. Michael Weinlich, Peter Kurz, Melissa B. Blau, Felix Walcher, Stefan Piatek. Significant acceleration of emergency response using smartphone geolocation data and a worldwide emergency call support system. Plus One. May 23 , 2018. https://doi.org/10.1371/journal.pone.0196336

35. Soltani H, Furness PJ, Arden MA, et al. Women's and Midwives' Perspectives on the Design of a Text Messaging 
Support for Maternal Obesity Services: An Exploratory Study. JObes.2012;2012:835464.doi:10.1155/2012/835464

36. Tammy J. Toney-Butler; Wendy J. Unison-Pace. Nursing Admission Assessment and Examination.2019. Available from: https://www.ncbi.nlm.nih.gov/books/NBK493211/ 